\title{
Crimean-Congo Hemorrhagic Fever Virus: Current Advances and Future Prospects of Antiviral Strategies
}

\author{
Shiyu Dai ${ }^{1}$, Fei Deng ${ }^{1,2, *(\mathbb{D})}$, Hualin Wang ${ }^{1,2, *}$ and Yunjia Ning ${ }^{1,2, *}$ \\ 1 State Key Laboratory of Virology and National Virus Resource Center, Wuhan Institute of Virology, \\ Chinese Academy of Sciences, Wuhan 430071, China; daishiyu@wh.iov.cn \\ 2 Center for Biosafety Mega-Science, Chinese Academy of Sciences, Wuhan 430071, China \\ * Correspondence: df@wh.iov.cn (F.D.); h.wang@wh.iov.cn (H.W.); nyj@wh.iov.cn (Y.N.); \\ Tel./Fax: +86-27-8719-8465 (F.D.); +86-27-8719-9353 (H.W.); +86-27-8719-7200 (Y.N.)
}

check for updates

Citation: Dai, S.; Deng, F.; Wang, H.; Ning, Y. Crimean-Congo Hemorrhagic Fever Virus: Current Advances and Future Prospects of Antiviral Strategies. Viruses 2021, 13, 1195. https://doi.org/10.3390/ v13071195

Academic Editor: Leen Delang

Received: 29 April 2021

Accepted: 18 June 2021

Published: 22 June 2021

Publisher's Note: MDPI stays neutral with regard to jurisdictional claims in published maps and institutional affiliations.

Copyright: (c) 2021 by the authors. Licensee MDPI, Basel, Switzerland. This article is an open access article distributed under the terms and conditions of the Creative Commons Attribution (CC BY) license (https:// creativecommons.org/licenses/by/ $4.0 /)$

\begin{abstract}
Crimean-Congo hemorrhagic fever virus (CCHFV) is a widespread, tick-borne pathogen that causes Crimean-Congo hemorrhagic fever (CCHF) with high morbidity and mortality. CCHFV is transmitted to humans through tick bites or direct contact with patients or infected animals with viremia. Currently, climate change and globalization have increased the transmission risk of this biosafety level (BSL)-4 virus. The treatment options of CCHFV infection remain limited and there is no FDA-approved vaccine or specific antivirals, which urges the identification of potential therapeutic targets and the design of CCHF therapies with greater effort. In this article, we discuss the current progress and some future directions in the development of antiviral strategies against CCHFV.
\end{abstract}

Keywords: Crimean-Congo hemorrhagic fever virus; bunyavirus; tick-borne virus; antiviral strategies

\section{Introduction}

Crimean-Congo hemorrhagic fever virus (CCHFV) is a tick-borne virus causing Crimean-Congo hemorrhagic fever (CCHF), a severe hemorrhagic fever in humans, with a mortality rate of up to $30 \%$ in more than 30 countries in Asia, Africa, southeastern Europe, and the Middle East [1]. The virus is transmitted to humans by the bites of infected ticks of the Hyalomma genus, or direct contact with tissue or body fluids from infected animals and humans [2]. A large variety of animals, such as cattle, donkeys, goats, hares, horses, ostriches, small rodents, and sheep, develop viremia without noticeable symptoms of illness following CCHFV infection [3], despite its high pathogenicity in humans. Following viral challenge, newborn mice, a subset of immunocompromised rodents and cynomolgus macaques could partially recapitulate the human disease and have been assessed as potential animal models of CCHFV [3-5]. The limits of appropriate animal models, as well as the requirement of such a biosafety level (BSL)-4 virus for high-containment laboratories, largely slow down the progress in virological study and development of antiviral drugs and vaccines.

CCHFV belongs to the genus Orthonairovirus, family Nairoviridae, order Bunyavirales [6]. The viral genome is composed of three negative-sense RNA segments. The small (S) segment encodes the nucleoprotein (NP), the medium (M) segment encodes the glycoprotein precursor (GPC) that is subsequently cleaved into mature Gn, Gc, and several nonstructural proteins including mucin, GP38 and NSm, and the large (L) segment encodes the L protein which contains the RNA-dependent RNA polymerase ( $\mathrm{RdRp}$ ) catalyzing viral RNA synthesis and an ovarian tumor (OTU) protease domain likely involved in viral antagonism of host innate immunity [7-9].

Due to the lack of specific antiviral therapies, high mortality rate, increased vector bionomics and climate change, CCHFV is considered an emerging arboviral zoonotic disease in many countries and is listed as a highly infectious pathogen that could cause a public health emergency. Thus, the development of novel antiviral therapeutics against 
CCHFV is urgently needed to manage the increasing public health threat of CCHF. Currently, supportive therapy is the primary mode of treatment. Ribavirin, a broad-spectrum antiviral medication, has been administered to human cases of CCHF; however, the therapeutic benefits remain elusive [10]. Other therapeutic candidates utilized in case reports include steroid, convalescent serum, and specific immunoglobulin, although there is no sufficient evidence to assess the efficiency of these medicaments [11]. In addition, potential inhibitors of bunyaviruses have been evaluated over the past decades and some of them have demonstrated possible efficacy to CCHFV infection. In this article, we review these current antiviral strategies of CCHFV (Table 1) and discuss some future directions for further research.

Table 1. Summary of antivirals against CCHFV.

\begin{tabular}{|c|c|c|c|c|c|c|c|}
\hline Antiviral Name & Type & Target & $\begin{array}{c}\text { In Vitro } \\
\text { (Cell Line) }\end{array}$ & In Vivo & $\begin{array}{l}\text { Effective } \\
\text { Spectrum }\end{array}$ & $\begin{array}{c}\text { Developmental } \\
\text { Stage }\end{array}$ & Reference \\
\hline Ribavirin & $\begin{array}{c}\text { Small } \\
\text { molecule }\end{array}$ & Viral RdRp & $\begin{array}{c}\text { SW13, } \\
\text { Huh7, Vero }\end{array}$ & $\begin{array}{c}\text { Suckling mice; } \\
\text { STAT-1 knockout mice; } \\
\text { IFNAR } /^{-} \text {mice; } \\
\text { STAT-2 knockout } \\
\text { hamster; } \\
\text { cynomolgus macaque; } \\
\text { certain clinical cases }\end{array}$ & $\begin{array}{l}\text { RSV, IAVs, LASV, } \\
\text { etc. }\end{array}$ & $\begin{array}{c}\text { Clinical drug for } \\
\text { HCV }\end{array}$ & {$[10,12-18]$} \\
\hline Favipiravir & $\begin{array}{c}\text { Small } \\
\text { molecule }\end{array}$ & Viral RdRp & SW13, Huh7 & $\begin{array}{c}\text { IFNAR }^{-} /^{-} \text {mice; } \\
\text { cynomolgus macaque }\end{array}$ & $\begin{array}{c}\text { RVFV, LASV, } \\
\text { EBOV, ZIKV, } \\
\text { SARS-CoV2, etc. }\end{array}$ & $\begin{array}{l}\text { Clinical drug for } \\
\text { influenza virus }\end{array}$ & [18-20] \\
\hline $\begin{array}{l}2^{\prime} \text {-deoxy-2'- } \\
\text { fluorocytidine }\end{array}$ & $\begin{array}{c}\text { Small } \\
\text { molecule }\end{array}$ & Viral RdRp & SW13, Huh7 & - & $\begin{array}{l}\text { RVFV, SFTSV, } \\
\text { HCV, HSV, } \\
\text { LASV, etc. }\end{array}$ & $\begin{array}{c}\text { Clinical trial for } \\
\text { HCV }\end{array}$ & [21] \\
\hline Phenanthrenequinone & $\begin{array}{c}\text { Small } \\
\text { molecule }\end{array}$ & Viral OTU & - & - & ${ }^{2}$ & Preclinical & [22] \\
\hline $\mathrm{UbV}-\mathrm{CC} 4$ & Protein & Viral OTU & A549 & - & - & Preclinical & {$[23,24]$} \\
\hline IFN- $\alpha$ & Protein & Immune system & $\begin{array}{l}\text { A549, Huh7, } \\
\text { HUVEC }\end{array}$ & certain clinical cases & $\begin{array}{l}\mathrm{HCV} \text {, IAVs, HSV, } \\
\text { etc. }\end{array}$ & $\begin{array}{c}\text { Clinical trial for } \\
\text { HCV }\end{array}$ & [25-27] \\
\hline IFN- $\lambda 1$ & Protein & Immune system & A549, Huh7 & - & $\begin{array}{c}\text { IAVs, ZIKV, RSV, } \\
\text { etc. }\end{array}$ & Preclinical & [27] \\
\hline 8A1, 11E7, 30F7 & Antibody & Viral Gc & SW13 & Suckling mice & - & Preclinical & [28-30] \\
\hline $6 \mathrm{~B} 12,11 \mathrm{~F} 6,7 \mathrm{~F} 5,8 \mathrm{~F} 10$ & Antibody & Viral Gn & SW13 & Suckling mice & - & Preclinical & [29] \\
\hline $13 \mathrm{G} 8$ & Antibody & Viral GP38 & SW13 & IFNAR $^{-} j^{-}$mice & - & Preclinical & [31] \\
\hline DVD-121-801 & Antibody & Viral Gc & Vero E6 & IFNAR $^{-} /^{-}$mice & - & Preclinical & [32] \\
\hline Chloroquine & $\begin{array}{l}\text { Small } \\
\text { molecule }\end{array}$ & $\begin{array}{l}\text { Endocytosis and } \\
\text { other pathways }\end{array}$ & $\begin{array}{l}\text { Vero E6, } \\
\text { Huh7 }\end{array}$ & - & $\begin{array}{l}\text { Flaviviruses, } \\
\text { retroviruses, } \\
\text { CoVs, etc. }\end{array}$ & $\begin{array}{l}\text { Clinical drug for } \\
\text { nonviral disease }\end{array}$ & [33] \\
\hline Chlorpromazine & $\begin{array}{c}\text { Small } \\
\text { molecule }\end{array}$ & $\begin{array}{l}\text { Endocytosis and } \\
\text { other pathways }\end{array}$ & $\begin{array}{l}\text { Vero E6, } \\
\text { Huh7 }\end{array}$ & - & EBOV, CoVs, etc. & $\begin{array}{l}\text { Clinical drug for } \\
\text { nonviral disease }\end{array}$ & [33] \\
\hline ТH3289, ТH6744 & $\begin{array}{c}\text { Small } \\
\text { molecule }\end{array}$ & $\begin{array}{l}\text { Protein folding } \\
\text { machinery }\end{array}$ & Vero & - & $\begin{array}{l}\text { SARS-CoV2, } \\
\text { EBOV }\end{array}$ & Preclinical & [34] \\
\hline
\end{tabular}

Abbreviations: RSV, respiratory syncytial adenovirus; IAV, influenza A virus; RVFV, Rift Valley fever virus; LASV, Lassa fever virus; EBOV, Ebola virus; ZIKV, Zika virus; SFTSV, Severe fever with thrombocytopenia syndrome virus; HCV, hepatitis C virus; HSV, herpes virus; $\mathrm{CoV}$, coronaviruses; SARS-CoV2, severe acute respiratory syndrome coronavirus 2; SW13, human adrenal gland cell line; Huh7, human hepatocarcinoma cell line; HUVEC, human umbilical vein endothelial cell line; Vero, African green monkey kidney cell line; A549, human lung carcinoma cell line; Vero E6, African green monkey kidney cell line, clone E6; STAT-1, signal transducer and activator of transcription-1; STAT-2, signal transducer and activator of transcription-2; IFNAR ${ }^{-} /^{-}$, interferon receptor knockout. -, no report or unclear.

\section{Current Antiviral Strategies}

\subsection{Nucleotide Analogues}

Nucleoside analogues, a class of drugs targeting viral RNA polymerase, exhibit broadspectrum antiviral activity against many distinct viruses both in vitro and in vivo. Many of them are currently being evaluated as candidate drugs for therapeutic use in emerging infections [35,36]. Several, including ribavirin, favipiravir and 2'-deoxy-2'-fluorocytidine, have also been used in anti-CCHFV tests.

\subsubsection{Ribavirin}

Ribavirin is a purine nucleoside analogue compound with known broad-spectrum antiviral activity in vitro and in vivo, and is the only antiviral drug recommended by the World Health Organization (WHO) for the treatment of CCHF. In 1989, Watts et al. reported the anti-CCHFV effectiveness of ribavirin by in vitro tests with African green monkey kidney cell line (Vero cells), in which the drug significantly decreased the replication of various CCHFV strains [12]. The protective activity of ribavirin was then examined in CCHFV- 
infected suckling mice [13], signal transducer and activator of transcription-1 (STAT-1) knockout mice [14] and type I interferon receptor deficient (IFNAR ${ }^{-}{ }^{-}$) mice $[18,19]$, which suggested that ribavirin treatment against CCHFV must be started soon after infection to see clinical benefit. However, clinical evidence for the beneficial treatment of ribavirin is inconsistent and has attracted debate among researchers and clinicians [10,17]. Systematic reviews and meta-analyses showed insufficient efficacy of ribavirin for CCHF patients [15], or suggested that early treatment with ribavirin, $<48 \mathrm{~h}$ after symptom onset, was needed for clinical benefit [16]. These various findings make the efficacy of ribavirin in CCHF patient inconclusive.

\subsubsection{Favipiravir}

Favipiravir (also known as T-705) is licensed in Japan for the treatment of influenza virus infections but has shown promise against other highly pathogenic RNA viruses including severe acute respiratory syndrome coronavirus 2 (SARS-CoV2), Hantavirus, and Rift Valley fever virus (RVFV), as well as CCHFV [36-38]. Two groups have evaluated favipiravir against CCHFV in a type I interferon-deficient mouse model and both showed that favipiravir treatment effectively suppresses viral replication in several tissues and can reduce mortality following diverse CCHFV strain infections [18,19]. Work by Oestereich et al. has shown that favipiravir treatment is efficacious in inhibiting viral replication and preventing a lethal outcome following CCHFV infection, even when treatment is started two days before the expected time of death [19]. Furthermore, they also demonstrated that favipiravir and ribavirin exert synergistic effects in vitro, allowing lower doses of both drugs to be used in vivo with clinical efficacy, suggesting that a combined treatment yields beneficial rather than adverse effects [19]. In the study by Hawman et al., favipiravir showed clinical benefit even when administered six days post-infection, a time point at which mice were exhibiting advanced disease, including death [18]. Their further study demonstrated that favipiravir has therapeutic efficacy against CCHFV infection in a cynomolgus macaque model. However, compared to the results from the mouse model, favipiravir treatment only showed a modest benefit in CCHFV-infected cynomolgus macaques, even though treatment was initiated $24 \mathrm{~h}$ post-infection, which may be attributed to the subcutaneous administration of favipiravir and nonuniform lethality of the cynomolgus macaque model [20] and needs further investigation to be clarified. Nevertheless, overall, these data suggest that favipiravir may be an effective antiviral for the treatment of advanced CCHF.

\subsubsection{2'-deoxy-2'-fluorocytidine}

In addition to ribavirin and favipiravir mentioned above, several other prominent broad-spectrum inhibitors against bunyavirus infections also have been reported. Welch et al. developed a high-throughput screening assay for CCHFV antiviral drug discovery using a recombinant CCHFV encoding a reporter protein. They identified a compound, $2^{\prime}$-deoxy-2'-fluorocytidine (also known as $2^{\prime}$-fluoro- $2^{\prime}$-deoxycytidin, $2^{\prime}$-dFC) as a potential CCHFV antiviral, with inhibitory activity superior to that of favipiravir or ribavirin in vitro. They also demonstrated that 2 - $\mathrm{dFC}$ acts synergistically with favipiravir to inhibit CCHFV replication without causing cytotoxicity, suggesting the potential of a combination therapy with $2^{\prime}-\mathrm{dFC}$ and favipiravir [21]. Smee et al. further investigated the potential of $2^{\prime}$-FdC as a broad-spectrum inhibitor of bunyaviruses in the IFNAR ${ }^{-} /^{-}$mouse model [39]. They indicated that 2 '-FdC has inhibitory effectiveness against both RVFV and severe fever with thrombocytopenia syndrome virus (SFTSV) and is thus a promising candidate for treating certain bunyavirus infections [39]. However, how 2'-FdC performs in animal models of CCHFV infection remains unclear.

\subsection{OTU Protease Inhibitors}

Many viruses encode deubiquitinating (DUB) enzymes that play an important role in viral replication and innate immune evasion. The CCHFV L protein contains an OTU 
domain also exhibiting DUB activity, which binds and removes ubiquitin (Ub) and interferon stimulated gene 15 (ISG15) from their protein targets to circumvent host antiviral innate immune responses $[7,40]$. This makes the DUB active site of CCHFV OTU a highly attractive drug target, as disrupting the activity is expected to not only directly interfere with viral replication but also enhance immune responses upon infection. Kocabas and Aslan developed a fluorescent reporter assay of CCHFV OTU protease to screen CCHFV OTU inhibitors that might possess potential antiviral activity against CCHFV. They showed noticeable OTU inhibitory activities of two molecules (especially the compound phenanthrenequinone) in vitro [22]. Zhang et al. screened a phage display library of billions of $\mathrm{Ub}$ variants $(\mathrm{UbVs}$ ) and showed that a UbV-CC4 could bind the CCHFV OTU with high levels of affinity and specificity in vitro and selectively blocked the deubiquitinating and deISGylating activities of CCHFV DUB [23]. Scholte et al. further demonstrated that stable occupancy of CCHFV OTU by UbV-CC4 strongly inhibits viral growth not only by inhibiting the IFN antagonist function of OTU but also by blocking the formation of RNP complexes [24]. These studies indicate the dual antiviral potential of targeting CCHFV OTU and provide an important conceptual basis for the development of OTU-specific antiviral drugs. Since the data of the antiviral potential of CCHFV OTU inhibitors were generated in vitro, further in vivo studies should be necessary.

\subsection{Interferon (IFN)}

The innate immune response is the first line of host defense against viral infections in mammalian cells [41,42]. Previous studies have shown that CCHFV infection results in the substantial secretion of type I interferons (IFNs), especially IFN- $\alpha$ and IFN- $\beta$, and subsequent upregulation of interferon-stimulated genes (ISGs) $[43,44]$. In the studies by Andersson et al., pre-treatment with IFN- $\alpha$ was shown to have antiviral activity against CCHFV in vitro, most likely due to the induction of ISGs such as MxA [45,46]. However, established CCHFV infection is almost insensitive to subsequent treatment with IFN- $\alpha$ and moreover, no positive clinical data is available on IFN use against CCHF by far [26,46]. In the only clinical application case, patients and contacts were administrated with human IFN- $\alpha$ at 1985 in South Africa, but it was discontinued due to the serious side-effects [25]. Recently, Bordi et al. demonstrated that type III IFN (IFN- $\lambda 1$ ) also has an anti-CCHFV activity, although it seems to be less effective compared with type I IFN (IFN- $\alpha$ ). In addition, an obvious antagonistic effect between IFN- $\lambda$ and IFN- $\alpha$ was observed in human A549 and Huh7 cell lines and remains to be elucidated [27].

\subsection{Antibody Therapy}

With antibody engineering advancing, antibody therapy has been growing steadily in recent years. Antibodies, especially monoclonal antibodies (mAbs), have been demonstrated to be effective in the treatment of several hemorrhagic fever virus-related infectious diseases with in vitro and in vivo models, including those caused by Ebola and Lassa viruses [47,48].

\subsubsection{Convalescent Serum}

In the case of CCHFV, immunotherapy has demonstrated some clinical benefits in small studies. Vaccine studies in mice have shown that antibodies play an important role in preventing CCHFV infection $[49,50]$. Convalescent serum from donors has been used in several cases of CCHF patients and especially administering by the intravenous infusion, at earlier time, for longer duration, and in volumes greater than $200 \mathrm{~mL}$ could result in a better outcome [11]. Specific human immunoglobulin (CCHF-Venin), derived from the plasma pool of boosted donors, was tested in seven CCHFV patients in Bulgaria and showed good therapeutic effects [51]. However, the effectiveness of convalescent serum has not been evaluated in randomized controlled clinical trials with large sample sizes and no studies have proven the efficacy of specific immunoglobulin for the post-exposure prophylaxis or treatment of CCHF [30]. Moreover, there are still a number of challenges that 
prevent the large-scale adoption of convalescent serum, such as limited sources, individual differences and the complexity of blood products. Therefore, serum or immunoglobulin from convalescent patients is usually used in emergencies.

\subsubsection{Monoclonal Antibodies}

In comparison with the convalescent serum from donors, neutralizing mAbs have high specificity, low immunogenicity and limited metabolic side effects and represent a promising therapeutic approach for the development of an effective treatment. BertolottiCiarlet et al. generated a panel of murine mAbs specific to the glycoprotein pre-Gn or Gc. They found that $\mathrm{mAbs}$ to Gc, but not Gn, neutralize CCHFV in SW-13 cells. However, only a subset of Gc mAbs exhibited a protective effect in mice after passive immunization, whereas some non-neutralizing $\mathrm{Gn}$ mAbs protected suckling mice from a lethal challenge with the CCHFV strain IbAr10200, suggesting that antibody activities against CCHFV depend not only on the neutralizing properties, but also on host factors and non-neutralizing antibody-dependent mechanisms [29]. The same group also characterized the broadly cross-reactive neutralizing activity of their previously described murine mAb 11E7 [28]. Zivcec et al. further confirmed three anti-Gc murine mAbs (8A1, 11E7, and 30F7) showing cross-neutralization potency against CCHFV in vitro using a virus-like particle system in biosafety level 2 conditions and identified peptide binding regions of them [30]. Golden et al. then investigated the protection of these mAbs reported to target CCHFV pre-Gn or Gc using adult type I IFN-deficient mice. They demonstrated that, interestingly, a nonneutralizing antibody actually binding to GP38 (a secreted nonstructural glycoprotein in CCHFV), 13G8, protects the mouse model against lethal CCHFV infection [31]. Considering the immune rejection of human immune system to animal-derived antibodies, these murine $\mathrm{mAbs}$ need further humanized modification if they are used in clinic. In comparison, $\mathrm{mAbs}$ from patients are safer and worth isolation and functional testing. Furthermore, the use of a single antibody often only has limited efficacy and may be easy to induce tolerance. Strategies, e.g., antibody cocktail therapy and antibody-drug coupling, which can improve the biological activity of antibodies, will enhance the efficacy of antibody therapy. During the revision of this review, Fels et al. reported the isolation of a panel of neutralizing mAbs targeting CCHFV glycoproteins from convalescent donors [32]. To generate antibodies with increased antiviral activity and limited risk to induce viral escape mutation, they engineered bispecific antibodies bearing variable domains from two antibodies with a synergistic effect and successfully identified one antibody, DVD-121-801, that affords both prophylactic and therapeutic potential against CCHFV challenge in IFNAR ${ }^{-} /^{-}$mice [32].

Although antibody treatment for CCHF remains in its infancy, this approach may be an effective therapy against CCHFV in the absence of approved drugs.

\subsection{Other Potential Antivirals}

Targeting host cell pathways supporting viral replication is an attractive approach for the development of antiviral intervention strategies. CCHFV enters the cells via a clathrinand early endosome-dependent pathway, which can be potential targets of treatments for infections [52]. Ferraris et al. investigated the anti-CCHFV activity of FDA-approved molecules targeting endocytic pathways. In their in vitro antiviral testing, chloroquine and chlorpromazine that interfere with the clathrin/ $\mathrm{pH}$-dependent endocytic pathway were identified as potential antiviral drugs for CCHFV [33]. Chloroquine and chlorpromazine are widely used anti-malarial or anti-psychotic drugs, respectively. The two compounds also show antiviral activity against multiple viruses, including members of the flaviviruses, retroviruses, and coronaviruses $[53,54]$. Chloroquine and chlorpromazine both blocked a post-entry step in CCHFV replication cycle on two permissive cells-Vero E6 and Huh7. Chloroquine was found to be the more selective CCHFV inhibitor with a selective index of more than 20. However, the low selectivity index of chlorpromazine diminishes its potential use in clinic, particularly if this drug is used alone. Chloroquine or chlorpromazine and ribavirin combination assays demonstrated synergistic effects, suggesting that 
combinatorial treatment may be a better strategy to control CCHFV infection. The efficacy of these two FDA-approved drugs against CCHFV infection should be further confirmed in animal models.

Tampere et al. established an image-based phenotypic high-throughput screening assay coupled with automated image analysis and tested a set of in-house small molecule inhibitors targeting oxidative stress and nucleotide metabolism pathways. The newly identified antiviral molecules, TH3289 and TH6744, exhibited broad antiviral activity against emerging RNA viruses including SARS-CoV-2, Ebola virus (EBOV), Hazara virus, as well as CCHFV, likely due to its multifaceted effects on cellular heat shock protein 70 (HSP70) pathways [34].

RNA interference using small interfering RNAs (siRNAs) to silence genes might be used to regulate viral replication by targeting cellular processes such as those aforementioned or directly by targeting viral genes. Foldes et al. designed chemically synthesized siRNAs targeting viral genes that could inhibit CCHFV replication in vitro [55]. Therein, they identified effective siRNAs targeting all the three segments of the CCHFV genome, providing support for the potential use of RNA interference techniques in the rational design of anti-CCHFV drugs.

\section{Conclusions and Prospects}

CCHF is a medically important tick-borne viral disease of humans with wide prevalence and is listed by the $\mathrm{WHO}$ as one of the top priority diseases for research and development in public health emergency contexts (https:/ /www.who.int/activities/prioritizingdiseases-for-research-and-development-in-emergency-contexts, accessed on 21 June 2021). At present, medical countermeasures against CCHF remain controversial or experimental and the efficacy and safety of potential anti-CCHFV drugs also need comprehensive evaluation in standardized clinical trials. As a BSL-4 pathogen, CCHFV is strictly restricted to the special containment facilities for experimental manipulations of infections; moreover, suitable animal models also need to be further developed and optimized. Currently, they hamper virological studies and the assessments of prophylactic and therapeutic measures.

Since screening for antivirals in high-containment biosafety level settings is challenging, researchers have developed alternative methods. The entry-competent virus-like particle (tecVLP) system and recombinant fluorescent reporter virus which can be performed in the BSL-2 laboratory have been used in the initial screening of antivirals against CCHFV [21]. The identification of small molecule compounds inhibiting viral RNA synthesis can be conducted firstly with in vitro screening systems that rely on the availability of recombinant L protein or OTU protease and thus do not require high biosafety measures either $[9,22]$. In addition, computational virtual screening procedures provide both an alternative and a supplement to tiresome high-throughput screening, giving researchers the opportunity to hasten, facilitate and innovate the effectiveness of the overall drug discovery process. In the study by Sharifi et al., screening of FDA-approved drugs in silico indicated that doxycycline and minocycline are putative inhibitors of CCHFV NP [56]. Mirza et al. established an extensively refined homology model of CCHFV RdRp, which allowed the in silico predication of potential antiviral compounds [57]. The resolved structures of several critical CCHFV proteins, including NP, the OTU domain of $\mathrm{L}$, and glycoprotein (GP38), have and will continue to facilitate viral protein-targeting drug discovery based on structure and computational approaches [58-61].

In order to advance anti-CCHFV therapy development, animal models of CCHFV infection that can exhibit clinical signs similar to human disease are necessary in pre-clinical studies. Two adult mouse models of lethal CCHFV infection which lack the cell-surface IFN-I receptor (IFNAR ${ }^{-} /^{-}$) or the transcription factor essential for IFN signaling, STAT-1, have been reported and used for CCHFV pathogenesis and drug evaluation [3]. A lethal hamster model with a signal transducer and activator of transcription-2 (STAT-2) knockout has also been recently established. The efficacy of ribavirin against CCHF mortality shown in this hamster model demonstrates the model's ability to be used for the evaluation 
of promising CCHFV therapeutic candidates [5]. Apart from the immunocompromised rodents, a lethal humanized mouse model transplanted with human hematopoietic CD34+ stem cells [62] and an immunocompetent mouse model which developed disease following infection with a mouse-adapted variant of CCHFV have been reported [63]. Moreover, an immunocompetent cynomolgus macaque model has also been developed and used for the evaluation of the efficacy of favipiravir treatment against CCHFV infection $[4,20]$. This non-human primate model merits further tests and optimization in the evaluation of countermeasures against $\mathrm{CCHFV}$, e.g., in experimental settings with more appropriate administration approaches and viral dosages. Better understanding of virology and virushost interactions in the future may provide new clues for development of engineered animal models with specific virus-infection-associated host factor humanized, which are supposed to have significant advantages compared to those with common immune signaling proteins simply deleted. While current anti-CCHFV therapies have been assessed with limited animal models and clinical trials, future directions should focus on developing more appropriate animal models of CCHFV for the pre-clinical study of therapeutics.

Given the time-consuming nature of antiviral drug development and approval, repurposing the use of existing drugs in other conditions could be a strategy. For most of these drugs, ample experience is available with dosing in humans. Moreover, their safety, absorption, distribution, metabolism, and excretion profiles are well-known. The clinical drugs for non-viral disease, chloroquine and chlorpromazine, have been shown to be efficient in inhibiting CCHFV in vitro [33]. Despite the diversity of viruses, there are several common stages in the viral life cycle, including entry, biosynthesis, assembly, and release. The similar host processes and proteins exploited by virus usually serve as promising targets for the design of broad-spectrum, host-directed antiviral drugs. A notable challenge for the development of antiviral drugs is the virus mutation, especially for CCHFV, which is an RNA virus with a high mutation rate. Selective pressure from therapeutics targeting viral components could increase the probability of escape mutation, thus leading to the emergence of drug-resistant strains, while intervention strategies directing host factors would be more rigid to selective escape pressure and might have broad-spectrum antiviral potential. However, it should be noted that host proteins themselves usually have crucial cellular physiological functions; therefore, more comprehensive evaluation needs to be considered when targeting them for antiviral intervention. On the other hand, protein sequence and structure are similar among viruses from the same genus. Some vital viral proteins involved in viral infection, such as the catalytic domain of RNA polymerases, can also be considered as promising targets for the development of pan-virus or pan-genus antivirals. In the case of CCHFV, the antivirals tested are mostly targeting RdRp and OTU protease, which themselves are notable targets for drug design; the discovery and development of inhibitors to other essential and conserved viral components in the CCHFV life cycle also need to be considered.

In view of many obstacles to progress, CCHF will clearly remain a significant public health threat for the foreseeable future. Further advances in areas such as structure analysis of viral proteins, immunocompetent animal model development, and the study of virushost interaction would pave the way for effective medical countermeasures against CCHF. Additionally, successful research into CCHF therapeutics should also rely on collaboration among endemic countries.

Funding: The research in our laboratory was funded by the National Natural Science Foundation of China (31870162 and 82161138003, to Y.N.), the National Key Research and Development Program of China (2018YFA0507202, to Y.N. and H.W.), and the Youth Innovation Promotion Association of Chinese Academy of Sciences (to Y.N.).

Institutional Review Board Statement: Not applicable.

Informed Consent Statement: Not applicable.

Data Availability Statement: The data that support the findings of this study are available from the corresponding author upon reasonable request. 
Acknowledgments: We thank the Core Facility and Technical Support of the Wuhan Institute of Virology for technical assistance in the studies of our laboratory.

Conflicts of Interest: The authors declare no conflict of interest.

\section{References}

1. Spengler, J.R.; Bente, D.A.; Bray, M.; Burt, F.; Hewson, R.; Korukluoglu, G.; Mirazimi, A.; Weber, F.; Papa, A. Second International Conference on Crimean-Congo Hemorrhagic Fever. Antivir. Res. 2018, 150, 137-147. [CrossRef]

2. Papa, A.; Tsergouli, K.; Tsioka, K.; Mirazimi, A. Crimean-Congo Hemorrhagic Fever: Tick-Host-Virus Interactions. Front. Cell Infect. Microbiol. 2017, 7, 213. [CrossRef] [PubMed]

3. Mendoza, E.J.; Warner, B.; Safronetz, D.; Ranadheera, C. Crimean-Congo haemorrhagic fever virus: Past, present and future insights for animal modelling and medical countermeasures. Zoonoses Public Health 2018, 65, 465-480. [CrossRef] [PubMed]

4. Haddock, E.; Feldmann, F.; Hawman, D.W.; Zivcec, M.; Hanley, P.W.; Saturday, G.; Scott, D.P.; Thomas, T.; Korva, M.; AvsicZupanc, T.; et al. A cynomolgus macaque model for Crimean-Congo haemorrhagic fever. Nat. Microbiol. $2018,3,556-562$. [CrossRef]

5. Ranadheera, C.; Valcourt, E.J.; Warner, B.M.; Poliquin, G.; Rosenke, K.; Frost, K.; Tierney, K.; Saturday, G.; Miao, J.; Westover, J.B.; et al. Characterization of a novel STAT 2 knock-out hamster model of Crimean-Congo hemorrhagic fever virus pathogenesis. Sci. Rep. 2020, 10, 12378. [CrossRef] [PubMed]

6. Garrison, A.R.; Alkhovsky, S.V.; Avšič-Županc, T.; Bente, D.A.; Bergeron, É; Burt, F.; Di Paola, N.; Ergünay, K.; Hewson, R.; Kuhn, J.H.; et al. ICTV Virus Taxonomy Profile: Nairoviridae. J. Gen. Virol. 2020, 101, 798-799. [CrossRef] [PubMed]

7. Frias-Staheli, N.; Giannakopoulos, N.V.; Kikkert, M.; Taylor, S.L.; Bridgen, A.; Paragas, J.; Richt, J.A.; Rowland, R.R.; Schmaljohn, C.S.; Lenschow, D.J.; et al. Ovarian tumor domain-containing viral proteases evade ubiquitin- and ISG15-dependent innate immune responses. Cell Host Microbe 2007, 2, 404-416. [CrossRef] [PubMed]

8. Zivcec, M.; Scholte, F.E.; Spiropoulou, C.F.; Spengler, J.R.; Bergeron, E. Molecular Insights into Crimean-Congo Hemorrhagic Fever Virus. Viruses 2016, 8, 106. [CrossRef]

9. Tchesnokov, E.P.; Bailey-Elkin, B.A.; Mark, B.L.; Gotte, M. Independent inhibition of the polymerase and deubiquitinase activities of the Crimean-Congo Hemorrhagic Fever Virus full-length L-protein. PLoS Negl. Trop. Dis. 2020, 14, e0008283. [CrossRef]

10. Johnson, S.; Henschke, N.; Maayan, N.; Mills, I.; Buckley, B.S.; Kakourou, A.; Marshall, R. Ribavirin for treating Crimean Congo haemorrhagic fever. Cochrane Database Syst. Rev. 2018, 6, CD012713. [CrossRef]

11. Keshtkar-Jahromi, M.; Kuhn, J.H.; Christova, I.; Bradfute, S.B.; Jahrling, P.B.; Bavari, S. Crimean-Congo hemorrhagic fever: Current and future prospects of vaccines and therapies. Antivir. Res. 2011, 90, 85-92. [CrossRef] [PubMed]

12. Watts, D.M.; Ussery, M.A.; Nash, D.; Peters, C.J. Inhibition of Crimean-Congo hemorrhagic fever viral infectivity yields in vitro by ribavirin. Am. J. Trop. Med. Hyg. 1989, 41, 581-585. [CrossRef] [PubMed]

13. Tignor, G.H.; Hanham, C.A. Ribavirin efficacy in an in vivo model of Crimean-Congo hemorrhagic fever virus (CCHF) infection. Antivir. Res. 1993, 22, 309-325. [CrossRef]

14. Bente, D.A.; Alimonti, J.B.; Shieh, W.J.; Camus, G.; Stroher, U.; Zaki, S.; Jones, S.M. Pathogenesis and immune response of Crimean-Congo hemorrhagic fever virus in a STAT-1 knockout mouse model. J. Virol. 2010, 84, 11089-11100. [CrossRef]

15. Ascioglu, S.; Leblebicioglu, H.; Vahaboglu, H.; Chan, K.A. Ribavirin for patients with Crimean-Congo haemorrhagic fever: A systematic review and meta-analysis. J. Antimicrob. Chemother. 2011, 66, 1215-1222. [CrossRef]

16. Ergonul, O.; Keske, S.; Celdir, M.G.; Kara, I.A.; Pshenichnaya, N.; Abuova, G.; Blumberg, L.; Gonen, M. Systematic Review and Meta-analysis of Postexposure Prophylaxis for Crimean-Congo Hemorrhagic Fever Virus among Healthcare Workers. Emerg. Infect. Dis. 2018, 24, 1642-1648. [CrossRef]

17. Espy, N.; Perez-Sautu, U.; Ramirez de Arellano, E.; Negredo, A.; Wiley, M.R.; Bavari, S.; Diaz Menendez, M.; Sanchez-Seco, M.P.; Palacios, G. Ribavirin Had Demonstrable Effects on the Crimean-Congo Hemorrhagic Fever Virus (CCHFV) Population and Load in a Patient With CCHF Infection. J. Infect. Dis. 2018, 217, 1952-1956. [CrossRef]

18. Hawman, D.W.; Haddock, E.; Meade-White, K.; Williamson, B.; Hanley, P.W.; Rosenke, K.; Komeno, T.; Furuta, Y.; Gowen, B.B.; Feldmann, H. Favipiravir (T-705) but not ribavirin is effective against two distinct strains of Crimean-Congo hemorrhagic fever virus in mice. Antivir. Res. 2018, 157, 18-26. [CrossRef]

19. Oestereich, L.; Rieger, T.; Neumann, M.; Bernreuther, C.; Lehmann, M.; Krasemann, S.; Wurr, S.; Emmerich, P.; de Lamballerie, X.; Olschlager, S.; et al. Evaluation of antiviral efficacy of ribavirin, arbidol, and T-705 (favipiravir) in a mouse model for Crimean-Congo hemorrhagic fever. PLoS Negl. Trop. Dis. 2014, 8, e2804. [CrossRef]

20. Hawman, D.W.; Haddock, E.; Meade-White, K.; Nardone, G.; Feldmann, F.; Hanley, P.W.; Lovaglio, J.; Scott, D.; Komeno, T.; Nakajima, N.; et al. Efficacy of favipiravir (T-705) against Crimean-Congo hemorrhagic fever virus infection in cynomolgus macaques. Antivir. Res. 2020, 181, 104858. [CrossRef]

21. Welch, S.R.; Scholte, F.E.M.; Flint, M.; Chatterjee, P.; Nichol, S.T.; Bergeron, E.; Spiropoulou, C.F. Identification of 2'-deoxy-2' fluorocytidine as a potent inhibitor of Crimean-Congo hemorrhagic fever virus replication using a recombinant fluorescent reporter virus. Antivir. Res. 2017, 147, 91-99. [CrossRef]

22. Kocabas, F.; Aslan, G.S. Fluorometric CCHFV OTU protease assay with potent inhibitors. Virus Genes 2015, 51, 190-197. [CrossRef] 
23. Zhang, W.; Bailey-Elkin, B.A.; Knaap, R.C.M.; Khare, B.; Dalebout, T.J.; Johnson, G.G.; van Kasteren, P.B.; McLeish, N.J.; Gu, J.; He, W.; et al. Potent and selective inhibition of pathogenic viruses by engineered ubiquitin variants. PLoS Pathog. 2017, 13, e1006372. [CrossRef]

24. Scholte, F.E.M.; Hua, B.L.; Spengler, J.R.; Dzimianski, J.V.; Coleman-McCray, J.D.; Welch, S.R.; McMullan, L.K.; Nichol, S.T.; Pegan, S.D.; Spiropoulou, C.F.; et al. Stable Occupancy of the Crimean-Congo Hemorrhagic Fever Virus-Encoded Deubiquitinase Blocks Viral Infection. mBio 2019, 10. [CrossRef] [PubMed]

25. van Eeden, P.J.; van Eeden, S.F.; Joubert, J.R.; King, J.B.; van de Wal, B.W.; Michell, W.L. A nosocomial outbreak of Crimean-Congo haemorrhagic fever at Tygerberg Hospital. Part II. Management of patients. S. Afr. Med. J. 1985, 68, 718-721.

26. Andersson, I.; Lundkvist, A.; Haller, O.; Mirazimi, A. Type I interferon inhibits Crimean-Congo hemorrhagic fever virus in human target cells. J. Med. Virol. 2006, 78, 216-222. [CrossRef]

27. Bordi, L.; Lalle, E.; Caglioti, C.; Travaglini, D.; Lapa, D.; Marsella, P.; Quartu, S.; Kis, Z.; Arien, K.K.; Huemer, H.P.; et al. Antagonistic antiviral activity between IFN-lambda and IFN-alpha against lethal Crimean-Congo hemorrhagic fever virus in vitro. PLoS ONE 2015, 10, e0116816. [CrossRef]

28. Ahmed, A.A.; McFalls, J.M.; Hoffmann, C.; Filone, C.M.; Stewart, S.M.; Paragas, J.; Khodjaev, S.; Shermukhamedova, D.; Schmaljohn, C.S.; Doms, R.W.; et al. Presence of broadly reactive and group-specific neutralizing epitopes on newly described isolates of Crimean-Congo hemorrhagic fever virus. J. Gen. Virol. 2005, 86, 3327-3336. [CrossRef]

29. Bertolotti-Ciarlet, A.; Smith, J.; Strecker, K.; Paragas, J.; Altamura, L.A.; McFalls, J.M.; Frias-Staheli, N.; Garcia-Sastre, A.; Schmaljohn, C.S.; Doms, R.W. Cellular localization and antigenic characterization of crimean-congo hemorrhagic fever virus glycoproteins. J. Virol. 2005, 79, 6152-6161. [CrossRef]

30. Zivcec, M.; Guerrero, L.I.W.; Albarino, C.G.; Bergeron, E.; Nichol, S.T.; Spiropoulou, C.F. Identification of broadly neutralizing monoclonal antibodies against Crimean-Congo hemorrhagic fever virus. Antivir. Res. 2017, 146, 112-120. [CrossRef]

31. Golden, J.W.; Shoemaker, C.J.; Lindquist, M.E.; Zeng, X.; Daye, S.P.; Williams, J.A.; Liu, J.; Coffin, K.M.; Olschner, S.; Flusin, O.; et al. GP38-targeting monoclonal antibodies protect adult mice against lethal Crimean-Congo hemorrhagic fever virus infection. Sci. Adv. 2019, 5, eaaw9535. [CrossRef]

32. Fels, J.M.; Maurer, D.P.; Herbert, A.S.; Wirchnianski, A.S.; Vergnolle, O.; Cross, R.W.; Abelson, D.M.; Moyer, C.L.; Mishra, A.K.; Aguilan, J.T.; et al. Protective neutralizing antibodies from human survivors of Crimean-Congo hemorrhagic fever. Cell 2021. [CrossRef]

33. Ferraris, O.; Moroso, M.; Pernet, O.; Emonet, S.; Ferrier Rembert, A.; Paranhos-Baccala, G.; Peyrefitte, C.N. Evaluation of Crimean-Congo hemorrhagic fever virus in vitro inhibition by chloroquine and chlorpromazine, two FDA approved molecules. Antivir. Res. 2015, 118, 75-81. [CrossRef]

34. Tampere, M.; Pettke, A.; Salata, C.; Wallner, O.; Koolmeister, T.; Cazares-Korner, A.; Visnes, T.; Hesselman, M.C.; Kunold, E.; Wiita, E.; et al. Novel Broad-Spectrum Antiviral Inhibitors Targeting Host Factors Essential for Replication of Pathogenic RNA Viruses. Viruses 2020, 12, 1423. [CrossRef] [PubMed]

35. Graci, J.D.; Cameron, C.E. Mechanisms of action of ribavirin against distinct viruses. Rev. Med. Virol. 2006, 16, 37-48. [CrossRef]

36. Furuta, Y.; Gowen, B.B.; Takahashi, K.; Shiraki, K.; Smee, D.F.; Barnard, D.L. Favipiravir (T-705), a novel viral RNA polymerase inhibitor. Antivir. Res. 2013, 100, 446-454. [CrossRef]

37. Delang, L.; Abdelnabi, R.; Neyts, J. Favipiravir as a potential countermeasure against neglected and emerging RNA viruses. Antivir. Res. 2018, 153, 85-94. [CrossRef]

38. Kaptein, S.J.F.; Jacobs, S.; Langendries, L.; Seldeslachts, L.; Ter Horst, S.; Liesenborghs, L.; Hens, B.; Vergote, V.; Heylen, E.; Barthelemy, K.; et al. Favipiravir at high doses has potent antiviral activity in SARS-CoV-2-infected hamsters, whereas hydroxychloroquine lacks activity. Proc. Natl. Acad. Sci. USA 2020, 117, 26955-26965. [CrossRef] [PubMed]

39. Smee, D.F.; Jung, K.H.; Westover, J.; Gowen, B.B. 2'-Fluoro-2'-deoxycytidine is a broad-spectrum inhibitor of bunyaviruses in vitro and in phleboviral disease mouse models. Antivir. Res. 2018, 160, 48-54. [CrossRef]

40. Scholte, F.E.M.; Zivcec, M.; Dzimianski, J.V.; Deaton, M.K.; Spengler, J.R.; Welch, S.R.; Nichol, S.T.; Pegan, S.D.; Spiropoulou, C.F.; Bergeron, E. Crimean-Congo Hemorrhagic Fever Virus Suppresses Innate Immune Responses via a Ubiquitin and ISG15 Specific Protease. Cell Rep. 2017, 20, 2396-2407. [CrossRef]

41. Garcia-Sastre, A.; Biron, C.A. Type 1 interferons and the virus-host relationship: A lesson in detente. Science 2006, 312, 879-882. [CrossRef]

42. Zhou, J.H.; Wang, Y.N.; Chang, Q.Y.; Ma, P.; Hu, Y.; Cao, X. Type III Interferons in Viral Infection and Antiviral Immunity. Cell. Physiol. Biochem. 2018, 51, 173-185. [CrossRef]

43. Papa, A.; Mirazimi, A.; Koksal, I.; Estrada-Pena, A.; Feldmann, H. Recent advances in research on Crimean-Congo hemorrhagic fever. J. Clin. Virol. 2015, 64, 137-143. [CrossRef] [PubMed]

44. Kozak, R.A.; Fraser, R.S.; Biondi, M.J.; Majer, A.; Medina, S.J.; Griffin, B.D.; Kobasa, D.; Stapleton, P.J.; Urfano, C.; Babuadze, G.; et al. Dual RNA-Seq characterization of host and pathogen gene expression in liver cells infected with Crimean-Congo Hemorrhagic Fever Virus. PLoS Negl. Trop. Dis. 2020, 14, e0008105. [CrossRef]

45. Andersson, I.; Bladh, L.; Mousavi-Jazi, M.; Magnusson, K.E.; Lundkvist, A.; Haller, O.; Mirazimi, A. Human MxA protein inhibits the replication of Crimean-Congo hemorrhagic fever virus. J. Virol. 2004, 78, 4323-4329. [CrossRef]

46. Andersson, I.; Karlberg, H.; Mousavi-Jazi, M.; Martinez-Sobrido, L.; Weber, F.; Mirazimi, A. Crimean-Congo hemorrhagic fever virus delays activation of the innate immune response. J. Med. Virol. 2008, 80, 1397-1404. [CrossRef] [PubMed] 
47. Qiu, X.; Wong, G.; Audet, J.; Bello, A.; Fernando, L.; Alimonti, J.B.; Fausther-Bovendo, H.; Wei, H.; Aviles, J.; Hiatt, E.; et al. Reversion of advanced Ebola virus disease in nonhuman primates with ZMapp. Nature 2014, 514, 47-53. [CrossRef] [PubMed]

48. Cross, R.W.; Mire, C.E.; Branco, L.M.; Geisbert, J.B.; Rowland, M.M.; Heinrich, M.L.; Goba, A.; Momoh, M.; Grant, D.S.; Fullah, M.; et al. Treatment of Lassa virus infection in outbred guinea pigs with first-in-class human monoclonal antibodies. Antivir. Res. 2016, 133, 218-222. [CrossRef]

49. Buttigieg, K.R.; Dowall, S.D.; Findlay-Wilson, S.; Miloszewska, A.; Rayner, E.; Hewson, R.; Carroll, M.W. A novel vaccine against Crimean-Congo Haemorrhagic Fever protects $100 \%$ of animals against lethal challenge in a mouse model. PLoS ONE 2014, 9 , e91516. [CrossRef] [PubMed]

50. Dowall, S.D.; Graham, V.A.; Rayner, E.; Hunter, L.; Watson, R.; Taylor, I.; Rule, A.; Carroll, M.W.; Hewson, R. Protective effects of a Modified Vaccinia Ankara-based vaccine candidate against Crimean-Congo Haemorrhagic Fever virus require both cellular and humoral responses. PLoS ONE 2016, 11, e0156637. [CrossRef] [PubMed]

51. Vassilenko, S.M.; Vassilev, T.L.; Bozadjiev, L.G.; Bineva, I.L.; Kazarov, G.Z. Specific Intravenous Immunoglobulin for CrimeanCongo Hemorrhagic-Fever. Lancet 1990, 335, 791-792. [CrossRef]

52. Garrison, A.R.; Radoshitzky, S.R.; Kota, K.P.; Pegoraro, G.; Ruthel, G.; Kuhn, J.H.; Altamura, L.A.; Kwilas, S.A.; Bavari, S.; Haucke, V.; et al. Crimean-Congo hemorrhagic fever virus utilizes a clathrin- and early endosome-dependent entry pathway. Virology 2013, 444, 45-54. [CrossRef] [PubMed]

53. Rolain, J.M.; Colson, P.; Raoult, D. Recycling of chloroquine and its hydroxyl analogue to face bacterial, fungal and viral infections in the 21st century. Int. J. Antimicrob. Agents 2007, 30, 297-308. [CrossRef]

54. de Wilde, A.H.; Jochmans, D.; Posthuma, C.C.; Zevenhoven-Dobbe, J.C.; van Nieuwkoop, S.; Bestebroer, T.M.; van den Hoogen, B.G.; Neyts, J.; Snijder, E.J. Screening of an FDA-approved compound library identifies four small-molecule inhibitors of Middle East respiratory syndrome coronavirus replication in cell culture. Antimicrob. Agents Chemother. 2014, 58, 4875-4884. [CrossRef]

55. Foldes, F.; Madai, M.; Papp, H.; Kemenesi, G.; Zana, B.; Geiger, L.; Gombos, K.; Somogyi, B.; Bock-Marquette, I.; Jakab, F. Small Interfering RNAs Are Highly Effective Inhibitors of Crimean-Congo Hemorrhagic Fever Virus Replication In Vitro. Molecules 2020, 25, 5771. [CrossRef]

56. Sharifi, A.; Amanlou, A.; Moosavi-Movahedi, F.; Golestanian, S.; Amanlou, M. Tetracyclines as a potential antiviral therapy against Crimean Congo hemorrhagic fever virus: Docking and molecular dynamic studies. Comput. Biol. Chem. 2017, 70, 1-6. [CrossRef]

57. Mirza, M.U.; Vanmeert, M.; Froeyen, M.; Ali, A.; Rafique, S.; Idrees, M. In silico structural elucidation of RNA-dependent RNA polymerase towards the identification of potential Crimean-Congo Hemorrhagic Fever Virus inhibitors. Sci. Rep. 2019 , 9, 6809. [CrossRef] [PubMed]

58. Capodagli, G.C.; McKercher, M.A.; Baker, E.A.; Masters, E.M.; Brunzelle, J.S.; Pegan, S.D. Structural analysis of a viral ovarian tumor domain protease from the Crimean-Congo hemorrhagic fever virus in complex with covalently bonded ub: Iquitin. J. Virol. 2011, 85, 3621-3630. [CrossRef]

59. Guo, Y.; Wang, W.; Ji, W.; Deng, M.; Sun, Y.; Zhou, H.; Yang, C.; Deng, F.; Wang, H.; Hu, Z.; et al. Crimean-Congo hemorrhagic fever virus nucleoprotein reveals endonuclease activity in bunyaviruses. Proc. Natl. Acad. Sci. USA 2012, 109, 5046-5051. [CrossRef] [PubMed]

60. Wang, Y.; Dutta, S.; Karlberg, H.; Devignot, S.; Weber, F.; Hao, Q.; Tan, Y.J.; Mirazimi, A.; Kotaka, M. Structure of Crimean-Congo hemorrhagic fever virus nucleoprotein: Superhelical homo-oligomers and the role of caspase-3 cleavage. J. Virol. 2012, 86, 12294-12303. [CrossRef]

61. Mishra, A.K.; Moyer, C.L.; Abelson, D.M.; Deer, D.J.; El Omari, K.; Duman, R.; Lobel, L.; Lutwama, J.J.; Dye, J.M.; Wagner, A.; et al. Structure and Characterization of Crimean-Congo Hemorrhagic Fever Virus GP38. J. Virol. 2020, 94. [CrossRef] [PubMed]

62. Spengler, J.R.; Kelly Keating, M.; McElroy, A.K.; Zivcec, M.; Coleman-McCray, J.D.; Harmon, J.R.; Bollweg, B.C.; Goldsmith, C.S.; Bergeron, E.; Keck, J.G.; et al. Crimean-Congo Hemorrhagic Fever in Humanized Mice Reveals Glial Cells as Primary Targets of Neurological Infection. J. Infect. Dis. 2017, 216, 1386-1397. [CrossRef] [PubMed]

63. Hawman, D.W.; Meade-White, K.; Leventhal, S.; Feldmann, F.; Okumura, A.; Smith, B.; Scott, D.; Feldmann, H. Immunocompetent mouse model for Crimean-Congo hemorrhagic fever virus. eLife 2021, 10. [CrossRef] [PubMed] 